\title{
Prolonged Morphine Treatment Targets $\delta$ Opioid Receptors to Neuronal Plasma Membranes and Enhances $\delta$-Mediated Antinociception
}

\author{
Catherine M. Cahill ${ }^{1}$ Anne Morinville, ${ }^{1,2}$ Mao-Cheng Lee, ${ }^{1}$ Jean-Pierre Vincent, ${ }^{3}$ Brian Collier, ${ }^{2}$ and \\ Alain Beaudet ${ }^{1}$ \\ 1Department of Neurology and Neurosurgery, Montreal Neurological Institute, Montréal, Québec, Canada H3A 2B4, \\ 2Department of Pharmacology and Therapeutics, McGill University, Montréal, Québec, Canada, H3G 1Y6, and 3/nstitut \\ de Pharmacologie Moléculaire et Cellulaire, Centre National de la Recherche Scientifique, Université de Nice, 06560 \\ Valbonne, France
}

Opioid receptors are known to undergo complex regulatory changes in response to ligand exposure. In the present study, we examined the effect of morphine on the in vitro and in vivo density and trafficking of $\delta$ opioid receptors ( $\delta \mathrm{ORs})$. Prolonged exposure (48 hr) of cortical neurons in culture to morphine (10 $\mu \mathrm{M})$ resulted in a robust increase in the internalization of Fluodeltorphin, a highly selective fluorescent $\delta \mathrm{OR}$ agonist. This effect was $\mu$-mediated because it was entirely blocked by the selective $\mu$ opioid receptor antagonist D-Phe-Cys-Tyr-D-TrpOrn-Thr-Pen-Thr- $\mathrm{NH}_{2}$ and was reproduced using the selective $\mu$ agonist fentanyl citrate. Immunogold electron microscopy revealed a marked increase in the cell surface density of $\delta$ ORs in neurons exposed to morphine, indicating that the increase in Fluo-deltorphin internalization was caused by increased receptor availability. Prolonged morphine exposure had no effect on $\delta O R$ protein levels, as assessed by immunocytochemistry and Western blotting, suggesting that the increase in bioavailable

Endogenous as well as exogenous opioids are known to act through at least three distinct opioid receptor subtypes referred to as $\mu, \delta$, and $\kappa$. These three receptor subtypes have been cloned and were shown to belong to the G-protein-coupled receptor (GPCR) family (Evans et al., 1992; Kieffer et al., 1992; Chen et al., 1993; Fukuda et al., 1993; Meng et al., 1993; Thompson et al., 1993; Wang et al., 1993; Yasuda et al., 1993). Activation of one or more of these receptors by opioid ligands has been demonstrated to affect various physiological functions, including pain perception, locomotion, motivation, reward, autonomic function, immunomodulation, and hormone secretion.

Although each subtype of opioid receptor can transduce its effects independently, evidence has been accumulating for the existence of cellular and/or molecular interactions between them. Thus, cross-talk between $\mu$ and $\delta$ receptors was proposed on the

Received March 1, 2001; revised July 18, 2001; accepted July 20, 2001.

This work was supported by a grant from the Canadian Institutes of Health Research (CIHR) awarded to A.B. C.M.C. was funded by AstraZeneca R\&D Montreal and CIHR. A.M. was funded by the Natural Sciences and Engineering Research Council of Canada. We extend our gratitude to Mariette Houle, Alexander Jackson, and Naomi Takeda for technical assistance. We also thank Drs. C. Bushnell, M. Salter, and A. Basbaum for their critical review of this manuscript.

C.M.C. and A.M. contributed equally to this work.

Correspondence should be addressed to Dr. Alain Beaudet, Department of Neurology and Neurosurgery, Montreal Neurological Institute, Room 896, 3801 University Street, Montréal, Québec, Canada, H3A 2B4. E-mail: alain.beaudet@mcgill.ca. Copyright (C) 2001 Society for Neuroscience $0270-6474 / 01 / 217598-10 \$ 15.00 / 0$
¿ORs was caused by recruitment of reserve receptors from intracellular stores and not from receptor neosynthesis. Complementary in vivo studies demonstrated that chronic treatment of adult rats with morphine (5-15 mg/kg, s.c., every $12 \mathrm{hr}$ ) similarly augmented targeting of $\delta$ ORs to neuronal plasma membranes in the dorsal horn of the spinal cord. Furthermore, this treatment markedly potentiated intrathecal $\mathrm{D}-\left[\mathrm{Ala}^{2}\right]$ deltorphin II-induced antinociception. Taken together, these results demonstrate that prolonged stimulation of neurons with morphine markedly increases recruitment of intracellular $\delta \mathrm{ORs}$ to the cell surface, both in vitro and in vivo. We propose that this type of receptor subtype cross-mobilization may widen the transduction repertoire of G-protein-coupled receptors and offer new therapeutic strategies.

Key words: opiate; trafficking; narcotic; internalization; analgesia; receptor recruitment

basis of pharmacological studies demonstrating both competitive and noncompetitive changes in the binding of $\delta$-selective radioligands on exposure to $\mu$-selective ones (Rothman et al., 1986; Gouardères et al., 1993). Conversely, administration of $\delta$ opioid receptor $(\delta \mathrm{OR})$ antagonists, or of antisense oligonucleotides directed against the $\delta \mathrm{OR}$, were shown to reduce the development of tolerance to the antinociceptive effects of morphine (Miyamoto et al., 1993; Bilsky et al., 1996; Kest et al., 1996). Accordingly, $\delta$ OR knock-out mice maintained $\mu \mathrm{OR}$-mediated analgesia but showed a decrease in the development of tolerance to morphine (Zhu et al., 1999). Recent evidence using transfected cell systems demonstrated direct molecular interactions between different members of the opioid receptor family, with reports of heterodimerization of the $\delta$ OR with either the $\mu$ OR (George et al., 2000; Gomes et al., 2000) or $\kappa \mathrm{OR}$ (Jordan and Devi, 1999). However, the time frame of these molecular associations cannot account for all of the reported interactions between $\mu \mathrm{OR}$ and $\delta \mathrm{OR}$. Furthermore, these observations in artificial cell systems are difficult to reconcile with reports that in mammalian CNS, $\mu$ ORs are found mainly on the cell surface, whereas $\delta$ ORs are almost exclusively intracellular (Arvidsson et al., 1995a,b; Cheng et al., 1997; Cahill et al., 2001).

In the present study, we describe a new mechanism that could underlie interactions between $\mu \mathrm{ORs}$ and $\delta \mathrm{ORs}$ in vivo and might potentially be exploited to enhance the analgesic effects of $\delta \mathrm{OR}$ 
agonists. This was accomplished using both neuroanatomical and molecular approaches in vitro and in vivo to demonstrate that stimulation of $\mu \mathrm{ORs}$ induces the targeting of $\delta$ ORs from intracellular compartments to the plasma membrane.

\section{MATERIALS AND METHODS}

Cortical neuronal culture. Cerebral cortices were isolated from the brains of newborn (P0) Sprague Dawley rats, washed with HBSS (Life Technologies-BRL, Grand Island, NY), and incubated in the presence of trypsin-EDTA (Life Technologies-BRL) for $15 \mathrm{~min}$ at $37^{\circ} \mathrm{C}$. After washing, the cells were mechanically separated by gentle trituration through fire-polished Pasteur pipettes of decreasing bore diameter. The cell suspension was filtered through a $70 \mu \mathrm{m}$ sterile filter, and cells were plated onto poly-L-lysine-coated coverslips at a density of $2 \times 10^{5}$ cells or onto poly-L-lysine-coated $100 \mathrm{~mm}$ Petri dishes at a density of $2-4 \times 10^{6}$ cells. The growth medium was composed of DMEM (Life TechnologiesBRL) supplemented with $20 \mathrm{mM} \mathrm{KCl,} 110 \mathrm{mg} / 1$ sodium pyruvate, $2 \mathrm{~mm}$ glutamine, $0.9 \%$ glucose, $0.1 \%$ penicillin and streptomycin (Life Technologies-BRL), $0.5 \%$ fungizone, $2 \%$ B27 (Life Technologies-BRL), and $1-2 \%$ fetal bovine serum (Harlan, Indianapolis, IN). Neurons were routinely maintained in culture for $10 \mathrm{~d}$ without any change of growth medium, in a humidified incubator at $37^{\circ} \mathrm{C}$ with $5 \% \mathrm{CO}_{2}$.

Chronic treatment of neurons in vitro. Six to $8 \mathrm{~d}$ after plating, fully differentiated neurons were treated, or not, with a single application of the specified drug(s) for $48 \mathrm{hr}$. Stock solutions of naloxone hydrochloride (Sigma, St. Louis, MO), morphine sulfate (Sabex, Boucherville, Québec, Canada), fentanyl citrate (Sabex), and D-Phe-Cys-Tyr-D-Trp-Orn-ThrPen-Thr- $\mathrm{NH}_{2}$ (CTOP) (RBI, Natick, MA) were prepared in distilled water. Naloxone, morphine, and morphine with CTOP were added to the growth medium to yield a final concentration of $10 \mu \mathrm{M}$ for each drug, whereas fentanyl was added to yield a final concentration of $100 \mathrm{~nm}$. At the end of the $48 \mathrm{hr}$ incubation, cells were washed to remove residual drug(s) before subsequent manipulations (internalization assay, immunostaining, and Western blotting).

Binding of $\omega$-Bodipy red-deltorphin in primary cortical cultures. Internalization of the fluorescent $\delta$ OR agonist, $\omega$-Bodipy 576/589 deltorphin-I 5APA (Fluo-DLT) was visualized and quantified in primary cortical neurons using confocal microscopy. For this purpose, neurons were preincubated for $10 \mathrm{~min}$ at $37^{\circ} \mathrm{C}$ in Earles-HEPES (140 mM NaCl, $5 \mathrm{~mm}$ $\mathrm{KCl}, 1.8 \mathrm{mM} \mathrm{CaCl}_{2}, 0.9 \mathrm{mM} \mathrm{MgCl}_{2}$, and $\left.25 \mathrm{mM} \mathrm{HEPES}\right)$ binding buffer supplemented with $0.8 \mathrm{~mm}$ of the protease inhibitor 1,10 orthophenanthroline (Sigma), $0.09 \%$ glucose, and $0.2 \%$ BSA before the incubation with Fluo-DLT in the same buffer for $30 \mathrm{~min}$. Identical results were obtained whether or not morphine was added to the preincubation medium, indicating that the observed effects were not caused by the removal of morphine from the culture medium. To determine the specificity of Fluo-DLT binding, additional cells were labeled in the presence of the specific $\delta$ OR antagonist, ICI-174,864 (RBI). At the end of the incubation, cells were subjected to a hypertonic acid wash, $\mathrm{pH} 4.0$, to dissociate surface-bound ligand, and subsequently fixed with $4 \%$ paraformaldehyde (PFA). They were then rinsed with ice-cold EarlesHEPES buffer and examined under a Zeiss laser scanning microscope attached to an Axiovert 100 inverted microscope (Carl Zeiss Canada Ltd., Toronto, Ontario). Single optical sections were acquired through a trans-nuclear plane at eight scans per frame. Cellular morphology, as visualized by phase-contrast confocal microscopy, was used to identify neuronal phenotype. Acquired images were processed using Photoshop version 4.0.1 or 5.5 (Adobe Systems, San Jose, CA) on an IBMcompatible computer. Fluorescence intensity of acquired confocal images was quantified by converting the images to a gray scale and subsequently calculating the integrated density per unit area [in arbitrary units (AU)] using NIH ScionImage software program (Scion Corporation). Calculations and statistical analyses were performed using Excel 97 (Microsoft, San Francisco, CA) and Prism 3.02 (Graph Pad Software, San Diego, CA).

Immunofluorescence detection of $\delta O R$ in cultured neurons. Cultured neurons were quickly washed with $0.1 \mathrm{M}$ phosphate buffer (PB), pH 7.4, and immediately fixed with $4 \%$ PFA for $20-30 \mathrm{~min}$ at $37^{\circ} \mathrm{C}$. They were further washed with $0.1 \mathrm{M} \mathrm{PB}$ and $0.1 \mathrm{M}$ Tris-buffered saline (TBS), pH 7.4, and incubated overnight at $4^{\circ} \mathrm{C}$ with a blocking solution consisting of $10 \%$ normal goat serum (NGS), $0.1 \%$ Triton $\mathrm{X}-100$, and $2 \%$ BSA in 0.1 $\mathrm{M}$ TBS. They were then incubated for $48 \mathrm{hr}$ at $4^{\circ} \mathrm{C}$ with an N-terminally directed $\delta$ OR antiserum (Chemicon, Temecula, CA; AB1560 lot numbers 17080164 and 20010505 ), diluted to a concentration of $0.2-0.5 \mu \mathrm{g} / \mathrm{ml}$ in $0.5 \%$ NGS, $0.1 \%$ Triton $\mathrm{X}-100$ in $0.1 \mathrm{M}$ TBS, pH 7.4. Specificity of this antibody toward the rat $\delta \mathrm{OR}$ has been thoroughly characterized by both immunohistochemistry and Western blotting (Cahill et al., 2001). After extensive washing with $0.1 \mathrm{M}$ TBS, cells were incubated with either a Cy3- or Texas Red-conjugated goat anti-rabbit secondary antibody (Molecular Probes, Eugene, OR) for $30 \mathrm{~min}$ at $37^{\circ} \mathrm{C}$. Finally, cells were washed, and the coverslips were mounted onto gelatin-coated slides using Aquamount. Specificity controls were obtained by replicating the experimental conditions in the absence of primary antibody or using $\delta \mathrm{OR}$ antiserum preabsorbed with antigenic peptide. Images were acquired as single trans-nuclear optical sections at eight scans per frame and processed by using Photoshop version 4.0.1/5.5 (Adobe Systems) on an IBM-compatible computer. Fluorescence intensity of acquired confocal images was quantified as described above. Calculations and statistical analyses were performed using Excel 97 (Microsoft) and Prism 3.02 (Graph Pad Software).

Western blotting experiments. On ice, primary cortical cells were quickly washed with $0.1 \mathrm{M} \mathrm{PB}$, pH 7.4, collected in $25 \mathrm{~mm}$ Tris, $1 \mathrm{~mm}$ EDTA, and $250 \mathrm{~mm}$ sucrose with protease inhibitors (Complete Protease inhibitor tablets, Roche Molecular Biochemicals, Laval, Québec, Canada), and pelleted by centrifuging at $10,000 \mathrm{rpm}$ for $10 \mathrm{~min}$ at $4^{\circ} \mathrm{C}$. The pellet was sonicated for $15 \mathrm{sec}$ in $5 \mathrm{~mm}$ Trisma base, $\mathrm{pH} 7.4$, with protease inhibitors. Samples were centrifuged at $20,000 \times g$ for $20 \mathrm{~min}$ at $4^{\circ} \mathrm{C}$, and the

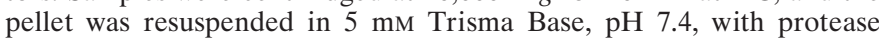
inhibitors. The membranes were subsequently denatured using $6 \times$ Laemmli sample buffer (0.375 mM Trisma base, pH 6.8, $12 \%$ w/v SDS, $30 \%$ v/v glycerol, $12 \%$ v/v 2-mercaptoethanol, $0.2 \% \mathrm{w} / \mathrm{v}$ bromophenol blue). Samples were resolved using 10\% Tris-glycine gels (Novex, San Diego, $\mathrm{CA})$, and the proteins were electroblotted onto nitrocellulose membranes. Molecular mass markers (Bio-Rad, Richmond, CA) were used to calibrate the gels. Nitrocellulose membranes were incubated with $1 \%$ BSA and $1 \%$ chicken egg albumin in $25 \mathrm{~mm}$ Tris with $150 \mathrm{~mm}$ sodium chloride containing $0.075 \%$ Tween 20 (TBST) at $4^{\circ} \mathrm{C}$ overnight to block nonspecific sites. Nitrocellulose membranes were then immunoblotted for $48 \mathrm{hr}$ at $4^{\circ} \mathrm{C}$ with the same $\delta \mathrm{OR}$ antisera as used for immunocytochemistry at a concentration of $0.2 \mu \mathrm{g} / \mathrm{ml}$ in TBST containing $1 \%$ BSA and $1 \%$ chicken egg albumin. Bound antibody was visualized using an HRP-conjugated goat anti-rabbit secondary antibody (Amersham Pharmacia Biotech, Baie D'Urfé, Québec, Canada) diluted 1:4000 in TBST and $5 \%$ milk powder followed by chemiluminescent reagents (NEN Life Science Products, Boston, MA). Blots were digitized by scanning with an Agfa Duoscan T1200, and image processing was performed using Photoshop version 4.0.1/5.5 imaging software (Adobe Systems) on an IBMcompatible computer.

Immunogold electron microscopic detection of $\delta O R s$ in cultured neurons. For electron microscopic localization of $\delta \mathrm{ORs}$, cells were washed quickly to remove growth medium and immediately fixed with a mixture of $2 \%$ acrolein $/ 2 \%$ PFA in $0.1 \mathrm{M} \mathrm{PB}$ and subsequently post-fixed with $2 \%$ PFA. Cells were washed thoroughly with $0.1 \mathrm{M}$ TBS, exposed to $3 \%$ NGS in 0.1 M TBS for $30 \mathrm{~min}$, and incubated for $24-48 \mathrm{hr}$ at $4^{\circ} \mathrm{C}$ with the anti- $\delta \mathrm{OR}$ antibody (Chemicon) diluted to a concentration of $0.2-0.5 \mu \mathrm{g} / \mathrm{ml}$ in 0.1 M TBS along with $0.2 \%$ Triton X-100 and $0.5 \%$ NGS. After incubation with the primary antibody, cells were washed repeatedly with $0.01 \mathrm{M} \mathrm{PBS}$ and nonspecific binding sites were blocked using $0.1 \%$ gelatin and $0.1 \%$ BSA diluted in 0.01 M PBS. Cells were then incubated with a 1:50 dilution of goat anti-rabbit IgG-gold (AuroProbe One GAR, Amersham Pharmacia Biotech) at room temperature for $2 \mathrm{hr}$. After thorough washing, cells were fixed with $2 \%$ glutaraldehyde, and immunogold deposits were enhanced by incubation with ionic silver in citrate buffer (IntenSE M Silver Enhancement Kit, Amersham Pharmacia Biotech). Subsequent to reaction amplification, cells were rinsed in buffer, post-fixed with $2 \%$ $\mathrm{OsO}_{4}$, dehydrated in graded alcohols, embedded in Epon, and sectioned at $80 \mathrm{~nm}$ thickness on an ultramicrotome. Sections were stained with uranyl acetate and lead citrate and examined with a JEOL 100CX transmission electron microscope (JEOL USA, Peabody, MA). Negatives were scanned using an AGFA Duoscan T1200, and images were processed using Photoshop version 4.0.1 (Adobe Systems) on an IBMcompatible computer.

For immunogold particle quantification, neurons were pooled from three separate experiments. Gold particles were designated as membrane-associated only if in actual contact with the plasma membrane; gold particles in close proximity to the plasma membrane were considered to be intracellular. Neurons with $<50$ gold grains were eliminated. Only neurons with a surface area between 30 and $100 \mu \mathrm{m}^{2}$, as measured by computer-assisted morphometry (BioCom, Les Ulis, 
France), were included in the analysis. The density of immunoreactive $\delta$ OR per unit length of membrane was calculated by dividing the number of gold particles detected at the surface of each neuron by its respective perimeter (measured by computer-assisted morphometry). The number of $\delta$ ORs per unit area (micrometers squared) was calculated by dividing the total number of gold particles detected over the entire cross-sectional profile of the neuron (including the nucleus) by its surface area (as measured by computer-assisted morphometry). The ratio of membraneassociated to intracellular gold particles was calculated for each labeled neuron by dividing the number of gold particles found at the cell surface by that detected as intracellular for each individual neuron. Statistical significance was verified using a Mann-Whitney $U$ test (two tailed). Calculations and statistical analyses were performed using Excel 97 (Microsoft) and Prism 3.02 (Graph Pad Software).

Chronic morphine treatment in vivo. Experiments were performed on adult male Sprague Dawley rats (220-250 gm; Charles River, Québec, Canada) housed in groups of two per cage. Rats were maintained on a 12 hr light/dark cycle and were allowed ad libitum access to food and water. Experiments were performed according to a protocol approved by the animal care committee at McGill University and in accordance with the policies and guidelines of the Canadian Council on Animal Care. Rats were injected with increasing doses of morphine sulfate in saline over a $48 \mathrm{hr}$ period $(5,8,10$, and $15 \mathrm{mg} / \mathrm{kg}$, s.c., every $12 \mathrm{hr})$. Rats were used 8-12 hr after morphine for thermal nociceptive testing and electron microscopy experiments, and 12-20 hr after morphine for formalin testing. An additional electron microscopy experiment was performed 1 hr after morphine treatment to ensure that the observed effects were not caused by opiate withdrawal. The results were identical to those obtained 8-12 hr after morphine.

Electron microscopic immunodetection of $\delta O R s$ in vivo. Rats $(n=3-4$ per group) were anesthetized with sodium pentobarbitol $(70 \mathrm{mg} / \mathrm{kg})$ and perfused through the aortic arch with $50 \mathrm{ml}$ of heparin $(75 \mathrm{U} / \mathrm{ml}$ heparin in $0.9 \%$ saline) followed by $50 \mathrm{ml}$ of a mixture of $3.75 \%$ acrolein and $2 \%$ PFA in $0.1 \mathrm{M} \mathrm{PB}, \mathrm{pH} 7.4$, and then by $400 \mathrm{ml}$ of $2 \%$ PFA in $0.1 \mathrm{M} \mathrm{PB}, \mathrm{pH}$ 7.4. Lumbar spinal cords were removed and post-fixed in $2 \%$ PFA in 0.1 M PB for $30 \mathrm{~min}$ at $4^{\circ} \mathrm{C}$. Transverse sections $(40 \mu \mathrm{m})$ were cut using a Vibratome series 1000 (Technical Products International, St. Louis, MO) and collected in PB. Spinal cord sections were incubated for $30 \mathrm{~min}$ with $1 \%$ sodium borohydride in PB followed by copious rinses with PB. Sections were then incubated for $30 \mathrm{~min}$ in a cryoprotectant solution consisting of $25 \%$ sucrose and $3 \%$ glycerol in $\mathrm{PB}$ before snap freezing with isopentane $\left(-70^{\circ} \mathrm{C}\right)$, immersion in liquid nitrogen, and thawing in PB. Sections were rinsed with $0.1 \mathrm{M}$ TBS and preincubated for $1 \mathrm{hr}$ at room temperature in blocking solution consisting of $3 \%$ NGS in TBS. They were then incubated overnight at $4^{\circ} \mathrm{C}$ in $\delta \mathrm{OR}$ antiserum (Chemicon) at a concentration of $0.2 \mu \mathrm{g} / \mathrm{ml}$ in TBS containing $0.5 \%$ NGS. After washing, sections were incubated for $2 \mathrm{hr}$ at room temperature with $1 \mathrm{~nm}$ colloidal gold-conjugated goat anti-rabbit IgG (1:50, Amersham Pharmacia Biotech) diluted in $0.1 \mathrm{M}$ PBS containing $2 \%$ gelatin and $8 \%$ BSA. Sections were then fixed for 10 min with $2 \%$ glutaraldehyde in $\mathrm{PB}$ and rinsed with $0.2 \mathrm{M}$ citrate buffer, $\mathrm{pH}$ 7.4. Immunogold particles were intensified with silver for $7 \mathrm{~min}$ using an IntenSE M kit (Amersham Pharmacia Biotech) and rinsed with citrate buffer to stop the reaction. Sections were post-fixed by incubation for $40 \mathrm{~min}$ at room temperature with $2 \% \mathrm{OsO}_{4}$ in $\mathrm{PB}$, rinsed, and dehydrated with increasing concentrations of ethanol. Sections were embedded in plastic by preincubation with Epon 812 and polypropylene oxide (1:1 then $3: 1$, respectively). The plastic mixture was replaced by $100 \%$ Epon 812 and incubated overnight at $4^{\circ} \mathrm{C}$ followed by placement between plastic coverslips at $60^{\circ} \mathrm{C}$ for $24 \mathrm{hr}$. Ultrathin sections $(80 \mathrm{~nm})$ were collected and counterstained with lead citrate and uranyl acetate for examination with a JEOL 100CX transmission electron microscope.

Immunolabeled $\delta \mathrm{OR}$ distribution was assessed in $\sim 200$ immunopositive dendrites photographed of three to four grids from three independent experiments for each condition. The distribution of immunogold particles was analyzed using computer-assisted morphometry (Biocom). First, the total number of immunogold particles per unit area was calculated for each labeled dendritic profile detected in both saline- and morphine-treated rats. A profile was considered labeled if it had more than one immunogold particle associated with it. Second, dendriteassociated immunogold particles were classified for each profile as being either intracellular or plasma membrane-associated. A gold particle was considered to be associated with the plasma membrane when it either contacted or overlaid it. Particles not in contact with the plasma membrane, even if in close proximity, were classified as intracellular. Intra- cellular particles were further categorized according to their distance (200 nm bins) from the plasma membrane. The total number of gold particles associated with the plasmalemma and those within various distances from the plasma membrane in the intracellular compartment were then expressed as a percentage of the total number of immunogold particles per dendrite. Statistical significance was verified using a MannWhitney $U$ test (two tailed) using Prism 3.02 (Graph Pad Software). Negatives were scanned using an AGFA Duoscan T1200, and images were processed using Photoshop version 4.0.1/5.5 (Adobe Systems) on an IBM-compatible computer.

Acute and persistent pain models. The hot plate test was used as an acute pain test whereby rats are placed on a fixed temperature hot plate $\left(52^{\circ} \mathrm{C}\right)$. Latency to response was determined by licking or vigorous shaking of either hind paw, at which point the rat was removed from the plate. A cutoff of $50 \mathrm{sec}$ was imposed to minimize tissue damage in the event that the rat did not respond. The formalin test was used as a model of persistent pain, whereby an intraplantar injection of formalin $(2.5 \%)$ produced a characteristic biphasic nociceptive response. Nocifensive behaviors were assessed using a weighed score as described previously (Coderre et al., 1993). Briefly, the nociceptive behavior was assessed as follows: (1) no favoring of the injected hind paw, (2) favoring, (3) complete elevation of the hind paw from the floor, and (4) licking or flinching. The behavior was evaluated in $5 \mathrm{~min}$ intervals, and the severity of the response was determined by the following formula: $(0 \times$ the time spent in category $1,+1 \times$ the time spent in category $2,+2 \times$ the time spent in category $3,+3 \times$ the time spent in category 4$)$. Dose-response curves were generated for each phase of the formalin test by calculating the area under the curve for each dose and expressing the results as a percentage of the area under the curve for the control. Phase 1 values were calculated between 0 and $10 \mathrm{~min}$. Phase 2 values were calculated between 15 and $45 \mathrm{~min}$. $\mathrm{ED}_{50}$ values for each dose-response curve were calculated using Prism 3.02 (Graph Pad Software).

\section{RESULTS \\ In vitro studies}

Incubation of neuronal cultures for $30 \mathrm{~min}$ at $37^{\circ} \mathrm{C}$ with the highly selective fluorescent $\delta$ OR agonist, Fluo-DLT, followed by hypertonic acid wash to dissociate surface-bound ligand, resulted in the weak fluorescent labeling of a small subset of neuronal cells ( $\sim 15 \%$ of neurons) (Fig. $1 A$ ). Coadministration of Fluo-DLT with the selective $\delta$ OR antagonist, ICI-174,864, completely abolished this fluorescent labeling, verifying the specificity of our fluorescent probe for $\delta$ ORs (data not shown). No specific (i.e., ICI-174,864-displaceable) staining was observed over glial cells. Fluo-DLT internalization was abolished when the incubation was performed in the presence of the endocytosis inhibitor, phenylarsine oxide, confirming that the fluorescence visualized by confocal microscopy corresponded to internalized ligand (data not shown).

Prolonged treatment of primary neuronal cultures with $10 \mu \mathrm{M}$ morphine before the internalization assay induced a significant increase in the amount of internalized Fluo-DLT when compared with untreated neurons $(\sim 234 \%$ of the control; $p<0.001)$ (Fig. $1 B, D)$. When neurons were concomitantly pretreated with morphine and the selective $\mu \mathrm{OR}$ antagonist, CTOP, there was no significant difference in Fluo-DLT internalization when compared with control, indicating that the morphine-induced increase in Fluo-DLT internalization was dependent on the interaction of morphine with $\mu \mathrm{OR}$ (Fig. 1C,D). Accordingly, treatment of primary cultures for $48 \mathrm{hr}$ with $100 \mathrm{~nm}$ fentanyl citrate, a highly selective $\mu \mathrm{OR}$ agonist, produced an increase in the internalization of Fluo-DLT that was not significantly different from that elicited by morphine ( $p>0.05$; data not shown). Treatment of neurons with $10 \mu \mathrm{M}$ somatostatin did not lead to any detectable increase in Fluo-DLT internalization (data not shown), indicating that this effect could not be produced by activation of any G-protein-coupled receptor. 

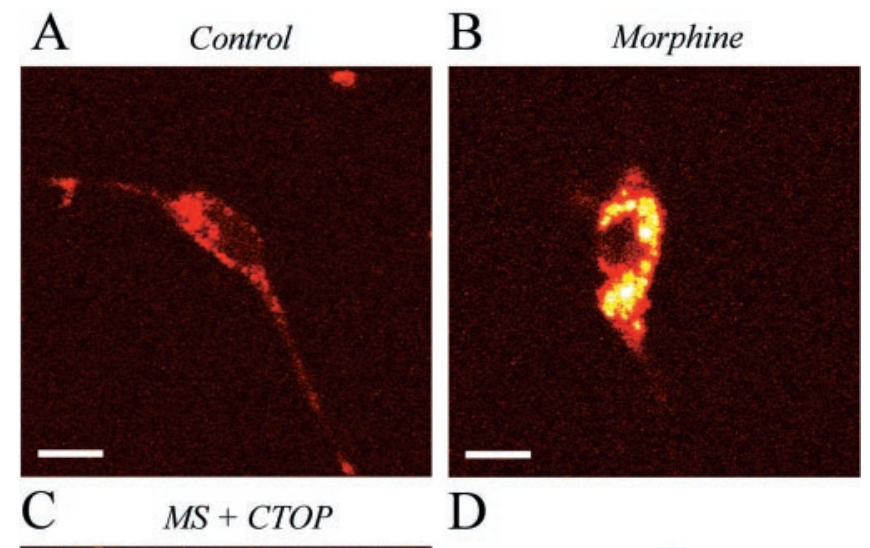

D
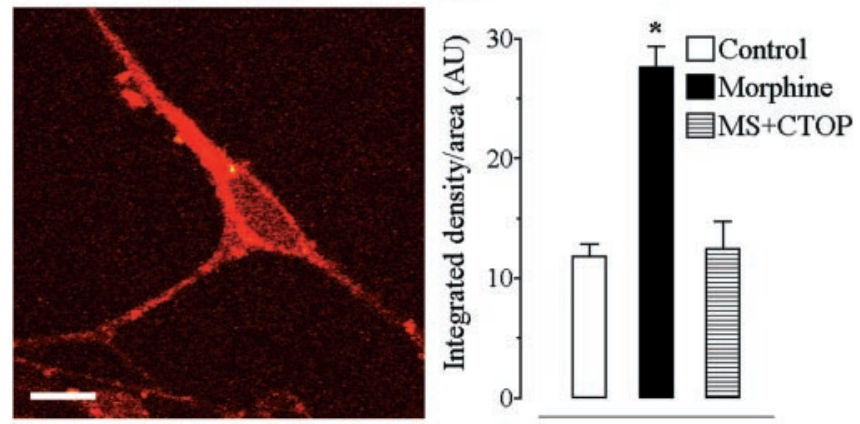

Figure 1. Chronic stimulation with morphine leads to $\mu$ OR-induced increase in bioavailable $\delta \mathrm{ORs}$ at the plasma membrane. Internalization of Fluo-DLT, a selective $\delta$ OR agonist, in primary cortical neurons either untreated $(A$, Control $)$ or treated with $10 \mu \mathrm{M}$ morphine sulfate for $48 \mathrm{hr}$ $(B)$ or treated with $10 \mu \mathrm{M}$ morphine sulfate $(M S)$ in the presence of $10 \mu \mathrm{M}$ of the $\mu$ OR antagonist CTOP $(C)$. Images are displayed in pseudocolor, where white represents the highest fluorescence intensity and red represents the lowest. Internalized Fluo-DLT can clearly be seen intracellularly, especially in morphine-treated cells. Note the absence of internalized ligand in the nucleus. Scale bar, $10 \mu \mathrm{m}$. $D$, Internalization of Fluo-DLT is significantly increased $(p<0.001)$ after treatment with morphine for $48 \mathrm{hr}$. This augmentation is no longer observed when morphine is administered in the presence of CTOP. Each bar in the graph represents the integrated density per area $( \pm$ SEM) pooled from at least three different experiments, with $n=13-38$ for each group. Statistical significance was determined using the Kruskal-Wallis test, followed by Dunn's multiple comparison test. The asterisk denotes significant differences between morphine-treated and untreated neurons $(p<0.001)$, as well as between morphine- and $M S+C T O P$-treated neurons $(p<0.001)$.

To determine whether the morphine-induced increase in the amount of internalized Fluo-DLT reflected an increase in cell surface $\delta$ ORs available for internalization, immunogold electron microscopy was used to monitor cell surface $\delta$ OR density. As can be seen in Figure 2, silver-intensified immunogold particles, corresponding to immunoreactive $\delta \mathrm{ORs}$, were evident both intracellularly and on the plasma membrane in untreated and morphine-treated primary cortical cells. However, the density of membrane-associated $\delta$ ORs per unit length of membrane was significantly higher in morphine-treated than in untreated neurons (Fig. 2C), suggesting that prolonged treatment with morphine increased cell surface $\delta$ ORs.

To investigate whether the morphine-induced increase in plasma membrane-associated $\delta \mathrm{ORs}$ was the result of receptor upregulation (i.e., of an increase in the synthesis of $\delta \mathrm{OR}$ proteins), total $\delta$ OR proteins were measured by Western blotting of membranes prepared from untreated and morphine-treated (10 $\mu \mathrm{M})$ cortical cells. Treatment of neuronal cultures with naloxone, a nonspecific opioid receptor antagonist documented to lead to

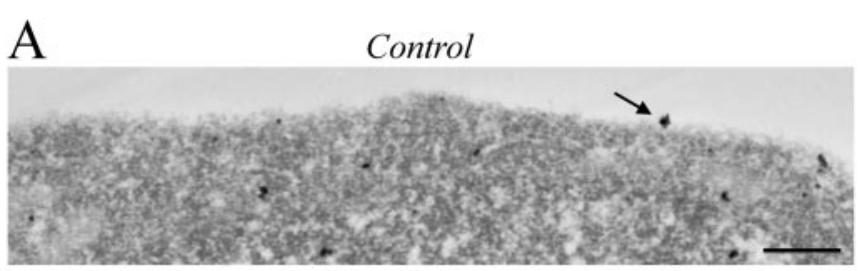

B

Morphine
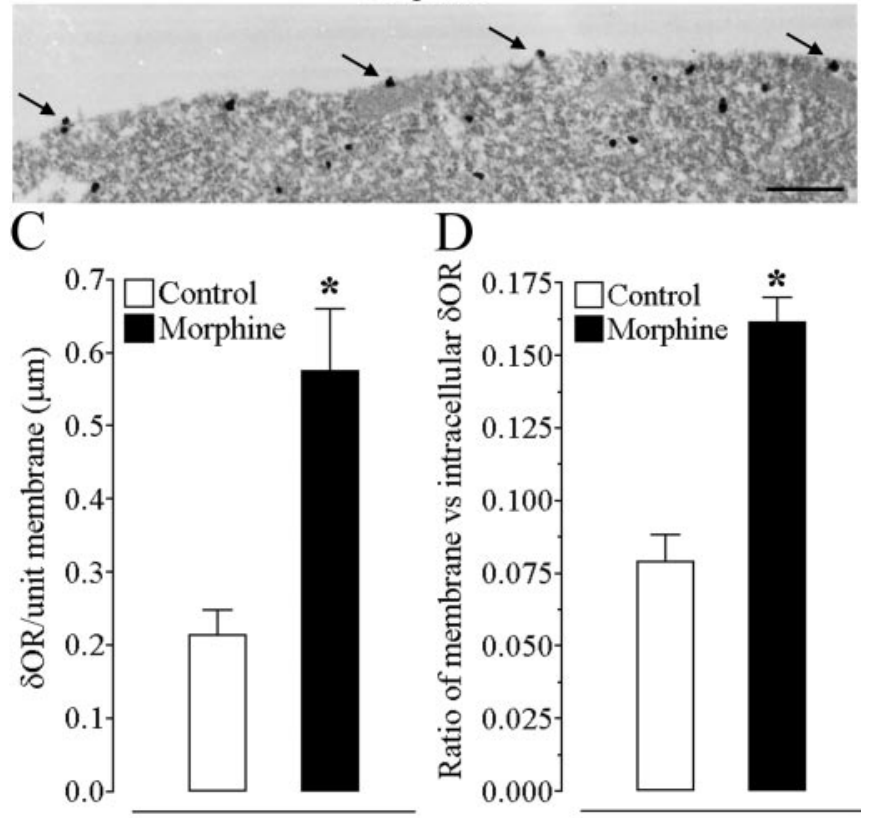

Figure 2. Morphine leads to increased plasma membrane-associated $\delta$ ORs as assessed by immunogold electron microscopy. Primary cortical cells were maintained in culture for $6-8 \mathrm{~d}$ before treatment, or not, with $10 \mu \mathrm{M}$ morphine sulfate for $48 \mathrm{hr}$, and subsequent processing for immunogold staining of $\delta$ ORs. In untreated ( $A$, Control) cortical neurons, immunogold particles are rarely associated with the cell surface (arrow), whereas in morphine-treated neurons $(B)$, cell surface-associated immunogold particles are more numerous (arrows). Scale bar, $0.5 \mu \mathrm{m}$. $C$, The number of membrane-associated gold particles per length of plasma membrane is significantly increased in primary cortical neurons treated for $48 \mathrm{hr}$ with $10 \mu \mathrm{M}$ morphine when compared with untreated controls. The asterisk indicates significant difference (two-tailed Mann-Whitney $U$ test; $p<0.002$ ) between morphine-treated and untreated neurons. $D$, The proportion of membrane-associated gold particles (expressed as the ratio of membrane-associated versus intracellular $\delta$ ORs per neuron) is significantly increased in primary cortical neurons treated for $48 \mathrm{hr}$ with $10 \mu \mathrm{M}$ morphine when compared with untreated controls, indicating a shift in receptors from an intracellular location toward the cell surface. The asterisk in $D$ indicates significant difference (two-tailed Mann-Whitney $U$ test, $p<0.0001$ ) between morphine-treated and untreated neurons.

increased $\delta$ OR protein expression (Belcheva et al., 1994; Zadina et al., 1994), was used as a positive control. In all cases, immunoreactive bands were observed at estimated molecular weights of 52, 59, 105, and $180 \mathrm{kDa}$ (Fig. 3). Bands at the lower molecular weights (52 and $59 \mathrm{kDa})$ most likely represent the monomeric form of the receptor, whereas the higher molecular weight forms (105 and $180 \mathrm{kDa}$ ) presumably correspond to protein-associated or oligomeric forms of the receptor (Cahill et al., 2001). A reproducible increase in the signal intensity of the $105 \mathrm{kDa}$ band was detected in neurons treated with naloxone but not in those treated with morphine when compared with the untreated cells (Fig. 3). By contrast, no reproducible change was detected in the intensity of any of the other immunoreactive bands after treatment with either $10 \mu \mathrm{M}$ naloxone or morphine for $48 \mathrm{hr}$ (Fig. 3). 


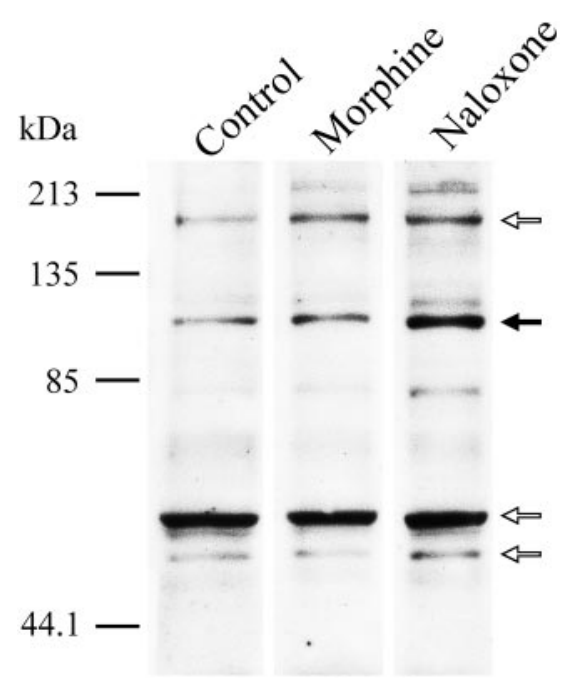

Figure 3. Comparison of the effect of naloxone and morphine on total $\delta$ OR protein expression. Dissociated primary cortical neurons were maintained in culture for $6-8 \mathrm{~d}$ and treated, or not, with $10 \mu \mathrm{M}$ naloxone or 10 $\mu \mathrm{M}$ morphine sulfate for $48 \mathrm{hr}$. Cell membranes were isolated, and the samples were resolved and immunoblotted with the $\delta \mathrm{OR}$ antisera. Major immunoreactive bands were observed at estimated molecular weights of $52,59,105$, and $180 \mathrm{kDa}$ (arrows). Specificity of this antibody has been characterized previously (Cahill et al., 2001). Immunoblot analysis reveals that treatment of cortical cells with $10 \mu \mathrm{M}$ naloxone for $48 \mathrm{hr}$, but not $10 \mu \mathrm{M}$ morphine for $48 \mathrm{hr}$, leads to an increased signal intensity of the band at $105 \mathrm{kDa}$ ( filled arrow), indicating augmented $\delta \mathrm{OR}$ protein expression. This increase was reproduced in three experiments.

To assess $\delta \mathrm{OR}$ protein concentrations at the single-cell level, both fluorescence and electron microscopic immunocytochemistry were used to complement the immunoblotting data. By confocal microscopy, $\delta \mathrm{OR}$ immunolabeling appeared characteristically punctate and was more pronounced at the level of cell bodies than processes (Fig. 4A-C). This labeling was specific, because it was no longer observed after either omission of the primary antibody or preabsorption of the antibody with antigenic peptide (data not shown). No increase in $\delta \mathrm{OR}$ immunolabeling density was detected either visually or by microdensitometry after $48 \mathrm{hr}$ exposure of cultured neurons to $10 \mu \mathrm{M}$ morphine when compared with untreated controls (Fig. $4 A, B, D$ ). By contrast, after $48 \mathrm{hr}$ treatment with naloxone, there was a significant augmentation of $\delta$ OR immunoreactivity $(p<0.0005)$ when compared with either morphine-treated or untreated neurons (Fig. $4 A, C, D$ ), indicating that the technique was sensitive enough to detect changes in $\delta \mathrm{OR}$ protein levels in our culture system. By electron microscopy, there was no significant increase in the overall density of immunogold particles (per unit area) in morphine-treated as compared with untreated neurons, although a trend toward an increased density was observed $\left(1.30 \pm 0.15\right.$ vs $2.11 \pm 0.31$ grains $/ \mu \mathrm{m}^{2}$ for untreated and morphine-treated neurons, respectively; $p>0.05)$. Immunoblotting and immunocytochemical data therefore concur in suggesting that increased protein synthesis is not the primary mechanism responsible for augmented plasma membraneassociated $\delta$ ORs.

To address the possibility that recruitment of intracellular reserve receptors to the cell surface was responsible for the increase in $\delta \mathrm{OR}$ plasma membrane density, the proportion of membrane-associated versus intracellular $\delta$ ORs was determined from our electron microscopic data. As can be seen in Figure 2D, the cell surface to intracellular immunoreactive receptor ratio
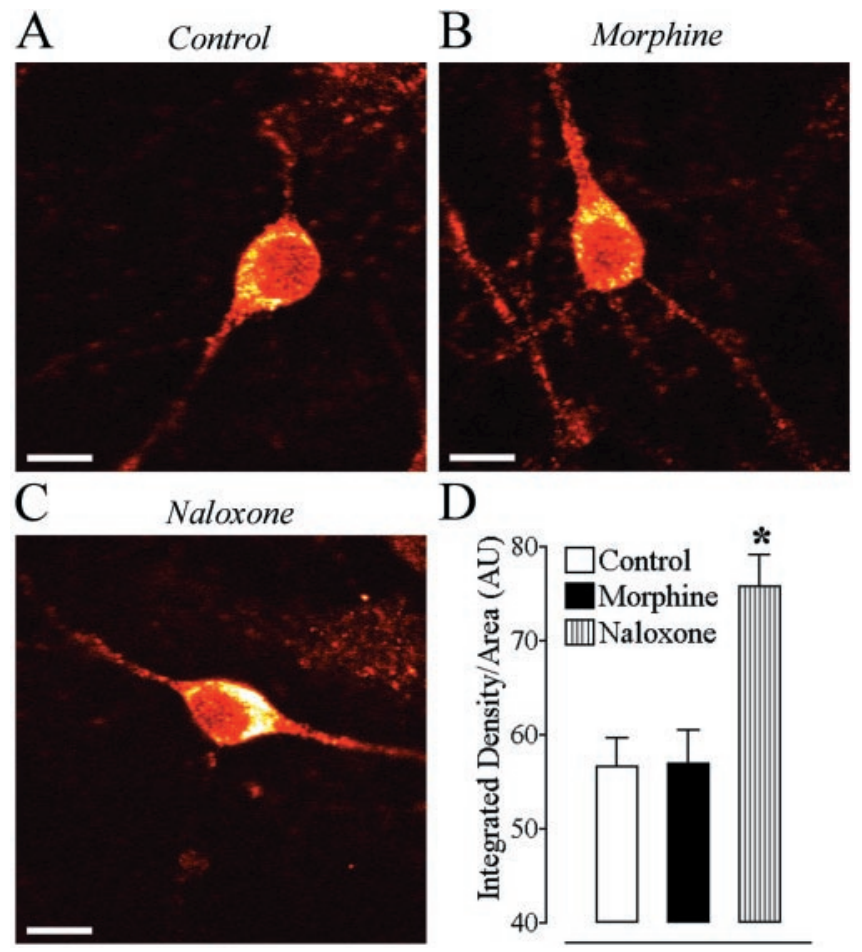

$\mathrm{D}$

Figure 4. Immunocytochemical determination of the effects of morphine and naloxone on $\delta \mathrm{OR}$ protein expression. Treatment with $10 \mu \mathrm{M}$ naloxone (C) for $48 \mathrm{hr}$ leads to a significant increase in fluorescent immunolabeling intensity when compared with either untreated $(A)$ or morphine-treated neurons $(B)$. Dissociated primary cortical cells were maintained in culture for $6-8 \mathrm{~d}$, treated or not with $10 \mu \mathrm{M}$ naloxone or $10 \mu \mathrm{M}$ morphine sulfate for $48 \mathrm{hr}$, and stained with the anti- $\delta \mathrm{OR}$ antibody and a Cy3-linked secondary antibody. Control refers to untreated neurons. Fluorescent images were acquired using a confocal microscope as described in Figure 1. Scale bar, $10 \mu \mathrm{m}$. $D$, As detected by immunocytochemistry, treatment with naloxone results in a significant increase in $\delta \mathrm{OR}$ protein levels when compared with either morphine-treated or untreated neurons. Each bar in the graph represents the integrated density per area ( \pm SEM) pooled from three different experiments, with $n=8$ for each condition in each experiment. A two-tailed Mann-Whitney $U$ test with a Bonferroni correction was used to determine statistical significance. The asterisk denotes significant differences between naloxone-treated and untreated neurons $(U$ statistic $=106 ; p<0.0005)$, as well as between morphine- and naloxone-treated neurons $(U$ statistic $=107 ; p<0.0005)$. There was no significant difference between untreated and morphine-treated neurons.

was significantly greater in neurons treated with $10 \mu \mathrm{M}$ morphine for $48 \mathrm{hr}$ when compared with untreated neurons ( 0.161 vs 0.079 , respectively; $p<0.0001)$, indicating that intracellular $\delta$ ORs were targeted to the cell surface in response to prolonged morphine stimulation.

\section{In vivo studies}

The study was subsequently extended to an in vivo animal model to assess the physiological relevance and possible pharmacological implications of our in vitro results. In a first set of experiments, electron microscopy was used to determine the subcellular distribution of $\delta \mathrm{OR}$ immunolabeling in the superficial dorsal horn of the lumbar spinal cord of both saline- and morphine-treated rats.

In both groups of animals, the vast majority of immunolabeled $\delta$ ORs was detected in association with perikarya and dendrites of small intrinsic neurons. Within these neurons, most of the immunoreactive $\delta \mathrm{ORs}$ were associated with intracellular compartments rather than with the plasma membrane (Fig. $5 A, B$ ). In accordance with our neuronal culture results, no significant increase in 

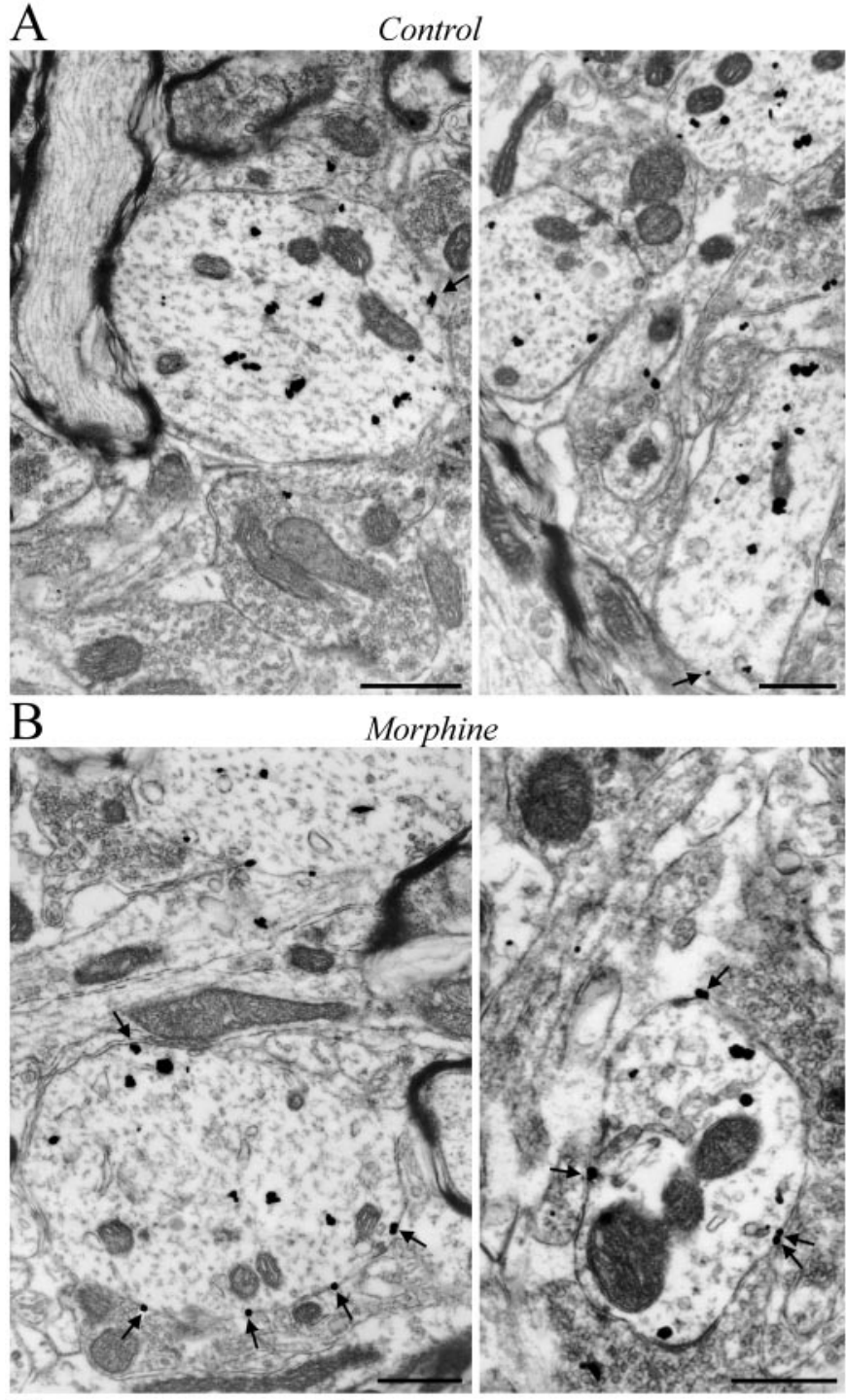

$\mathrm{C}$

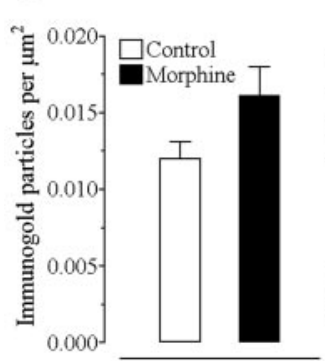

$\mathrm{D}$

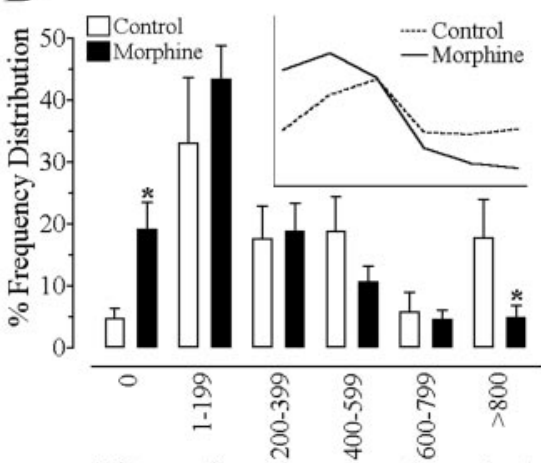

Distance from plasma membrane (nm)

Figure 5. Electron micrographs of $\delta \mathrm{OR}$-immunolabeled dendrites in the superficial dorsal horn of the spinal cord in saline- and chronic morphinetreated rats ( $n=3-4$ per group). In saline-treated rats $(A)$, few immunogold particles are evident on the plasma membrane (arrows), whereas in morphine-treated rats $(B)$, several immunogold particles are associated with it (arrows). Ultrastructural analysis reveals no significant difference in the number of gold particles per unit area of labeled dendritic profiles between treatment groups $(C)$. However, the percentage of gold particles associated with the plasma membrane is significantly higher in rats injected with morphine compared with saline-treated rats ( $D$, first column). A shortening of the mean distance separating intracellular immunogold the total number of immunogold particles was evident in morphine-treated compared with saline-injected rats, although a trend toward an increased number of $\delta$ ORs was suggested (Fig. $5 C$ ). However, all labeled dendrites showed a significantly higher ratio of plasma membrane-associated over total immunogold particles in morphine-treated as compared with saline-injected rats (Fig. 5D, first two columns; $p<0.0001$ ). Furthermore, the mean distance separating intracellular immunogold particles from the plasma membrane was significantly shorter in morphine-treated $(326 \pm 18.3 \mathrm{~nm})$ than in saline-treated animals $(514 \pm 32.4 \mathrm{~nm})$, indicating that morphine treatment resulted in a mobilization of intracellular $\delta$ ORs toward the plasmalemnal region (Fig. $5 D$ and inset).

One possible pharmacological corollary of the increase in spinal cell surface $\delta$ ORs produced by chronic morphine treatment is an augmentation in the pharmacological potency of $\delta \mathrm{OR}$ agonists. To test this possibility, antinociception produced by intrathecal administration of a selective $\delta$ OR agonist, [D-Ala ${ }^{2}$ ]deltorphin II (DELT), was assessed in paired saline- (control) and morphine-treated rats subjected to either one of the following pain paradigms: (1) phasic pain thresholds using the hot plate test and (2) the formalin test as a model of tonic pain. Rats were injected with morphine or saline subcutaneously every $12 \mathrm{hr}$ for $48 \mathrm{hr}$. At least 8-12 hr elapsed between the last morphine or saline injection and the evaluation of the effects of the $\delta$ agonist (Fig. 6A). Baseline thermal threshold latencies were the same in naïve, saline-, or morphine-treated rats. Thermal threshold latencies elicited by $10 \mu \mathrm{g}$ DELT were significantly increased ( $p<$ 0.05) in morphine-treated rats compared with controls (Fig. 6B). These effects were completely abolished in either morphine- or saline-treated groups by the application of naltrindole, a $\delta \mathrm{OR}$ antagonist, confirming the selectivity of DELT for the $\delta$ ORs (data not shown). At lower doses of DELT (3 $\mu \mathrm{g})$, no significant difference was observed between morphine-treated and control rats, although increased thermal latency was suggested. At higher doses of DELT, no change in hot plate latency was observed, which may be attributable to the limitations imposed to prevent physical injury to the animal.

Intrathecal DELT administration also elicited antinociception in a tonic pain model as exhibited by the inhibition of formalininduced nocifensive behaviors (Fig. 6C). Intrathecal DELT induced a dose-dependent antinociceptive effect in both control and morphine-treated rats (Fig. 6C). Here again, these effects were completely abolished by concomitant administration of the $\delta \mathrm{OR}$ antagonist naltrindole, indicating that these effects were $\delta$ OR-mediated (data not shown). A more prominent augmentation in the antinociceptive effects of DELT was evident in the group pretreated with morphine compared with control rats (Fig. $6 C, D)$. The dose-response curve for DELT-induced antinociception was significantly shifted to the left in morphine-treated rats compared with controls for both phases of the formalin test. Indeed, the $\mathrm{ED}_{50}$ values for the first phase of the formalin test were 3.19 and $7.71 \mu \mathrm{g}$, whereas for the second phase of the formalin response, the $\mathrm{ED}_{50}$ values were 4.9 and $32.4 \mu \mathrm{g}$ for morphine-treated and control rats, respectively (Fig. 6D).

particles from the plasma membrane is also observed $(D$, inset; $p<$ 0.0001). Statistical analysis comparing the pattern of labeling was performed using the Mann-Whitney $U$ test (two tailed) on the percentage of receptors localized in each divided compartment (distance for the plasma membrane) as well as the mean distance from the plasma membrane. Scale bar, $0.5 \mu \mathrm{m}$. 


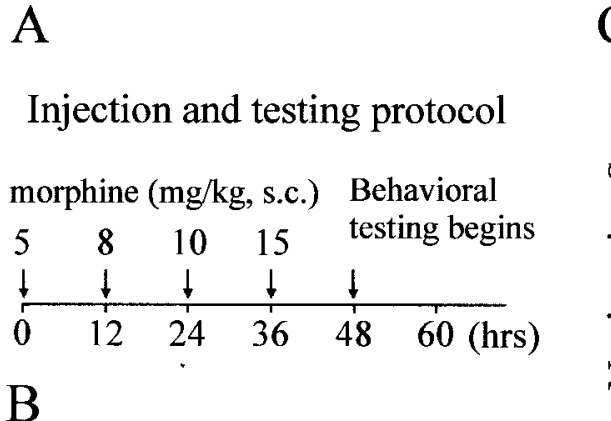

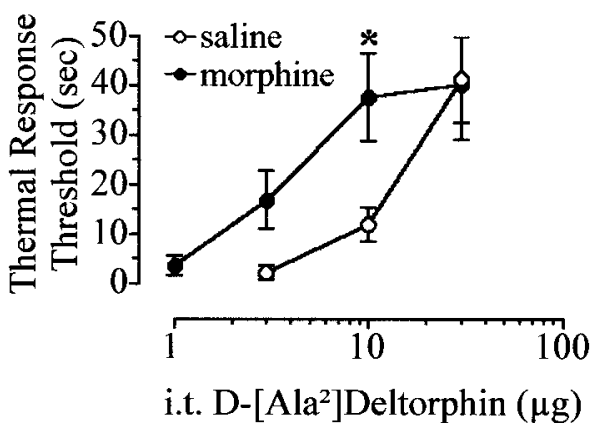

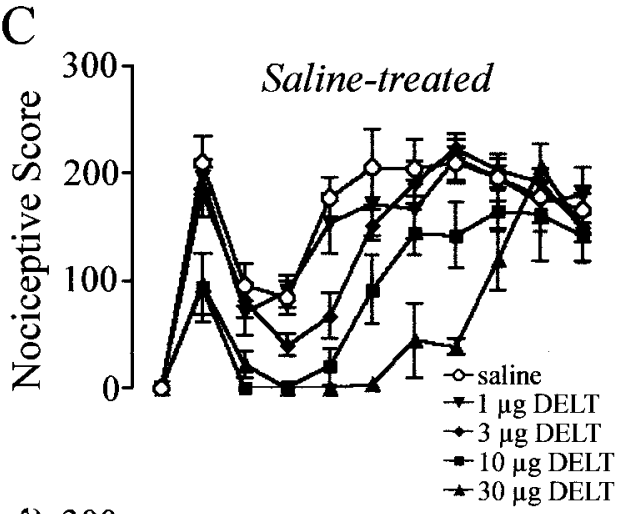

$\mathrm{D}$
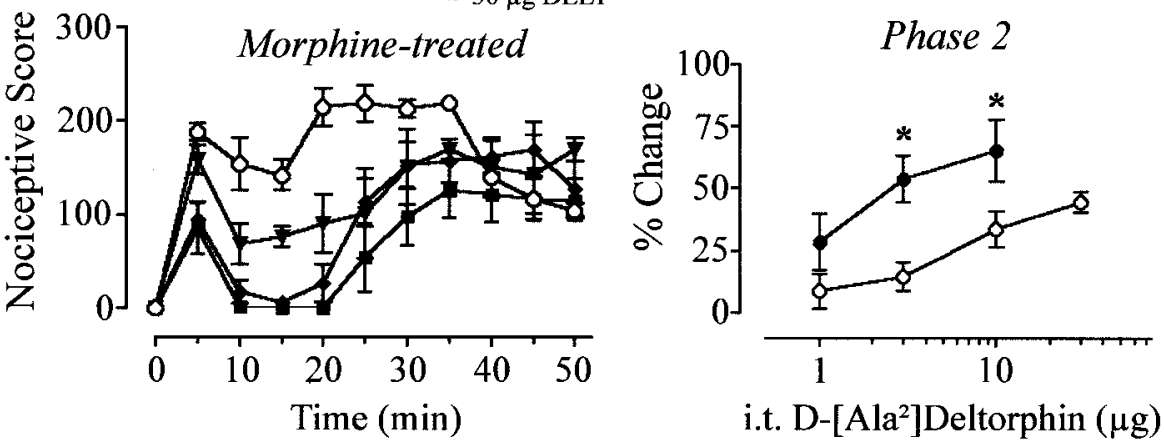

Figure 6. Rats chronically treated with morphine exhibit enhanced antinociceptive effects of intrathecal $\delta$ OR agonist in both thermal acute pain response $(B)$ and tonic pain $(C, D)$ compared with control rats. $A$, Diagram illustrating the testing and treatment regimen for morphine and saline injections of rats. The dose administered is indicated by arrows at each specified time point (hours). $B$, Response threshold to intrathecal administration of D-[Ala $\left.{ }^{2}\right]$ Deltorphin II (DELT) in the hot plate test ( $n=6$ per group). Statistical analysis using a two-tailed unpaired $t$ test revealed a significant difference between groups $(p<0.05)$, as denoted by the asterisk. $C$, Nocifensive behaviors assessed using a weighed score produced by intraplantar injection of formalin $(n=5-6$ per group). All testing was performed 8-20 hr after the final injection of morphine. $D$, Area under the curve values for phase 1 (time $0-10 \mathrm{~min}$ ) and phase 2 (time $15-40 \mathrm{~min}$ ) of the formalin test were converted to percentage change from control in respective groups to obtain antinociceptive dose-response curves. $\mathrm{ED}_{50}$ values for the first phase of the formalin test are $3.19 \mu \mathrm{g}$ for morphine-treated and $7.71 \mu \mathrm{g}$ for control rats. $\mathrm{ED}_{50}$ values for the second phase of the formalin response are 4.9 and $32.4 \mu \mathrm{g}$ for morphine-treated and control rats, respectively.

\section{DISCUSSION}

In the present study, we have demonstrated a novel type of interaction between $\mu$ and $\delta$ opioid receptors whereby prolonged in vitro stimulation of $\mu \mathrm{OR}$ enhances cell surface targeting, and hence bioavailability, of $\delta$ ORs. We also showed that this phenomenon could be elicited in vivo and that it was correlated with enhanced antinociceptive effects of $\delta \mathrm{OR}$ agonists.

\section{In vitro studies}

The selective fluorescent agonist, Fluo-DLT, used in the current study has previously been shown to internalize both in COS-7 cells transfected with cDNA encoding the $\delta$ ORs (Gaudriault et al., 1997) and in cortical neurons in culture (Cahill et al., 1999; Morinville et al., 2000; Lee et al., 2002). As confirmed by the present results, this internalization is receptor-dependent because it is completely abolished in the presence of the selective $\delta$ OR antagonist ICI-174,864. Such receptor dependency is consistent with the earlier demonstration of agonist-induced $\delta \mathrm{OR}$ internalization in neuronal-derived neuro2A cells stably transfected with HA- $\delta$ OR cDNA (Ko et al., 1999).

A major finding of the present study was that prolonged treatment of neuronal cultures with the $\mu$-preferring opioid agonist, morphine, markedly enhanced the amount of internalized FluoDLT. This increase in Fluo-DLT internalization could have resulted from either (1) an increased rate of receptor turnover whereby internalized receptors would be recycled more rapidly back to the cell surface for internalization of additional ligand molecules or (2) an increase in the density of the receptors at the plasma membrane at the onset of the internalization assay leading to a greater number of ligand molecules being internalized, as illustrated in Figure 7. To discriminate between these two possibilities, quantitative analysis of $\delta \mathrm{OR}$ cell surface density was performed using immunogold microscopy. Our results demonstrated a low number of cell surface $\delta \mathrm{ORs}$ in untreated cells, in agreement with previous reports to the effect that this receptor subtype is localized primarily intracellularly in vivo (Arvidsson et al., 1995a; Cheng et al., 1995, 1997; Zhang et al., 1998; Cahill et al., 2001). Pretreatment of the cells with morphine significantly increased $\delta \mathrm{OR}$ cell surface density, indicating that the observed increase in the Fluo-DLT internalization elicited by this drug was caused by an increase in the number of $\delta$ ORs accessible for activation and sequestration.

Three lines of evidence suggest that the morphine-induced increase in cell surface $\delta \mathrm{ORs}$ is attributable to an indirect effect via stimulation of $\mu \mathrm{ORs}$ rather than to a direct effect of the drug on $\delta$ ORs, to which morphine has been shown to bind in the range of concentrations used in the present study (Goldstein, 1987). First, direct stimulation of $\delta \mathrm{ORs}$ by morphine would have been expected to result in a decrease, rather than an increase, in cell surface $\delta \mathrm{OR}$ density, because stimulation with $\delta \mathrm{OR}$-selective agonists has been shown to result in a downregulation of this receptor (Zadina et al., 1994). Second, the increase in Fluo-DLT internalization was blocked by the addition of the selective $\mu$ antagonist CTOP, suggesting that morphine produced its effects through interaction with the $\mu$ ORs rather than with $\delta$ ORs. Third, 

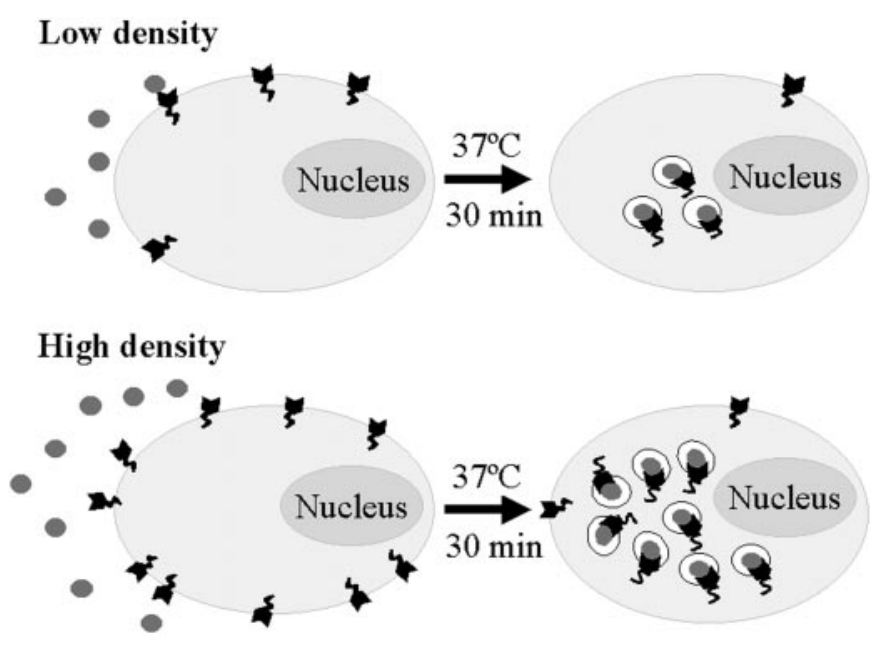

Figure 7. Schematic representation of the ligand-induced receptor internalization assay used to assess the density of plasma membrane-associated $\delta \mathrm{OR}$ receptors. At low receptor density on the plasma membrane, a small number of receptors can bind and internalize their cognate ligand at the permissive temperature of $37^{\circ} \mathrm{C}$. If, on the other hand, the receptor density on the plasma membrane is high at the start of the internalization assay, a greater number of receptors can undergo ligand-induced receptor internalization. Surface-bound ligand is removed by hypertonic acid-wash after ligand incubation to ensure that only intracellular ligand is detected. Chronic stimulation with morphine leads to $\mu \mathrm{OR}$-induced increase in bioavailable $\delta \mathrm{ORs}$ at the plasma membrane.

stimulation with the highly selective $\mu \mathrm{OR}$ agonist fentanyl citrate elicited an increase in Fluo-DLT internalization comparable to that produced by morphine.

The most obvious interpretation for the morphine-induced increase in the density of cell surface $\delta$ ORs was that stimulation of $\mu \mathrm{ORs}$ by morphine triggered an upregulation of $\delta \mathrm{OR}$ expression/synthesis. To test this possibility, we examined whether prolonged exposure to morphine altered $\delta \mathrm{OR}$ immunoreactive protein levels, as detected by either Western blotting or immunocytochemistry. Both experimental approaches concurred in demonstrating that total $\delta \mathrm{OR}$ protein levels remained unchanged after morphine treatment compared with controls. These results could not be attributed to a lack of sensitivity of our protein detection assays, because prolonged exposure to naloxone, a treatment documented to result in an upregulation of $\delta$ ORs (Zadina et al., 1994), produced a measurable increase in $\delta \mathrm{OR}$ protein content using either technique. The present results therefore suggest that, unlike naloxone, morphine induces its effect on $\delta$ ORs by increasing the recruitment to the plasma membrane of pre-existing intracellular reserve receptors. This interpretation was validated by quantitative immunogold electron microscopy demonstrating an upward shift in cell surface to intracellular receptor ratio.

\section{In vivo studies}

To determine whether the morphine-induced increase in $\delta \mathrm{OR}$ membrane targeting evidenced in vitro could also be elicited in vivo, animals were exposed to systemic morphine for an equivalent period of time, and the distribution of $\delta$ ORs was examined by electron microscopic immunohistochemistry in the dorsal horn of the spinal cord.

As demonstrated previously by us (Cahill et al., 2001) and others (Cheng et al., 1995), the bulk of $\delta$ OR immunoreactivity in the dorsal horn was detected in association with the perikarya and dendrites of intrinsic lamina II-III neurons. Also as described previously, only a small proportion of immunolabeled $\delta$ ORs were associated with the plasma membrane of either perikarya or dendrites in these regions (Arvidsson et al., 1995a; Cheng et al., 1995; Cahill et al., 2001). By contrast, in animals treated with morphine, a significantly higher plasma membrane to intracellular receptor ratio was observed, as in our in vitro model. Furthermore, this shift from the intracellular to the plasma membrane compartment was accompanied by a decrease in the mean segmental distance separating intracellular $\delta$ ORs from the plasma membrane, as expected from an outward movement of intracellular receptors from the core of the cell to the plasma membrane.

It has been well established that $\delta \mathrm{OR}$ agonists elicit antinociception in both acute and tonic pain models (Stewart and Hammond, 1993; Hammond et al., 1998). In the current study, we demonstrate that targeting of $\delta \mathrm{ORs}$ after morphine treatment translates into enhanced antinociceptive effects of $\delta \mathrm{OR}$ agonists in these two distinct pain paradigms. These findings indicate that the $\delta$ ORs newly recruited to the plasma membrane are functional and suggest that morphine could potentially be used as a primer to enhance the antinociceptive effects of $\delta \mathrm{OR}$ agonists.

Antinociceptive synergy between $\mu \mathrm{OR}$ and $\delta \mathrm{OR}$ agonists has been reported previously in various pain models (Heyman et al., 1989; Jiang et al., 1990; Porecca et al., 1990; Malmberg and Yaksh, 1992). However, in the present study, the enhanced antinociceptive effects of DELT are not caused by a synergistic interaction with morphine in so far as synergism is taken to reflect the simultaneous activation of different receptors or of their downstream effectors (Solomon and Gebhart, 1994). Indeed, all of our behavioral experiments were performed a minimum of $8 \mathrm{hr}$ after the last injection of morphine. Furthermore, no alterations in baseline latencies were evident between saline- and morphinetreated groups, nor was there any change in $\delta \mathrm{OR}$-induced antinociceptive effects after a single injection of morphine (data not shown). It is therefore more appropriate to interpret this increase in $\delta$ OR-elicited effects as being an adaptive response subsequent to chronic $\mu \mathrm{OR}$ stimulation. Although the enhanced $\delta \mathrm{OR}$ membrane labeling was not directly proven to be causative of the increased antinociceptive potency of the $\delta \mathrm{OR}$ agonist, its correlation with the augmented antinociceptive effectiveness of DELT strongly suggests that these two events are in fact related.

\section{Concluding remarks}

Earlier in vitro studies have proposed homologous or heterologous cell surface recruitment for regulating receptor responsiveness. For instance, somatostatin was reported to upregulate cell surface somatostatin type 5 receptors in transfected COS-7 cells (Stroh et al., 2000), insulin was reported to enhance recruitment of functional $\mathrm{GABA}_{\mathrm{A}}$ receptors in human embryonic kidney 293 cells expressing the $\alpha 1, \beta 2$, and $\gamma 2$ subunits of rat $\mathrm{GABA}_{\mathrm{A}}$ receptors (Wan et al., 1997), and neuropeptide $Y$ and atrial natriuretic peptide were reported to induce membrane recruitment of $\alpha_{1 \mathrm{~A}}$ receptors and dopamine D1 receptors, respectively, in a renal epithelial cell line (Holtbäck et al., 1999). Nonetheless, the present study is the first to demonstrate that membrane recruitment of heterologous receptors may be induced in vivo and that this mechanism may be harnessed for pharmacological purposes. It remains to be determined whether the $\mu \mathrm{OR}$-induced targeting of $\delta \mathrm{ORs}$ occurs in the same neuron or whether $\mu \mathrm{OR}$ stimulation of one neuron targets receptors to the cell surface of another. The cortical cultures used in the present experiments express both $\mu$ ORs and $\delta$ ORs (Lee et al., 2002), and a large proportion of neurons co-express both receptors (A. Morinville, 
unpublished observations). In the dorsal horn of the spinal cord, subcellular localization of $\mu \mathrm{ORs}$ and $\delta$ ORs likewise suggests that a proportion of spinal intrinsic neurons express both receptors (Cheng et al., 1997). If these $\mu \mathrm{OR}-\delta \mathrm{OR}$ interactions occur in the same cells, they might also involve $\mu \mathrm{OR}-$ $\delta \mathrm{OR}$ heterodimerization, a phenomenon that was recently demonstrated to occur in transfected cell systems (George et al., 2000; Gomes et al., 2000).

Earlier electron microscopic studies have reported an extensive association of immunoreactive $\delta$ ORs with large dense-core vesicles in axon terminals from the rat dorsal horn and have proposed neuropeptide exocytosis as a possible mechanism for $\delta \mathrm{OR}$ membrane targeting (Elde et al., 1995; Zhang et al., 1998). However, such a mechanism is unlikely to account for the $\mu \mathrm{OR}$-induced targeting of $\delta$ ORs observed in the present study because the bulk of upregulated $\delta \mathrm{ORs}$ was associated with dendrites, in which these receptors are rarely, if ever, associated with large densecore vesicles (Cheng et al., 1997; Cahill et al., 2001; this study).

The physiological consequence of the $\mu$-induced membrane targeting of $\delta$ ORs demonstrated in the present study is intriguing in that both opioid receptor subtypes can bind the same endogenous ligands, namely the enkephalins, albeit with different affinities (for review see Goldstein, 1987). Heterologous targeting of one receptor subtype by the other could therefore provide for a functional shift by which endogenously released enkephalins could exert a first set of physiological effects through interaction with $\mu \mathrm{ORs}$, followed by a second set of effects mediated by the newly recruited $\delta$ ORs. Pharmacologically, this mechanism might be exploited, as demonstrated here, to manipulate the subcellular distribution of $\delta$ ORs for enhanced agonist potency toward a desired clinical end-point. These results have exciting ramifications for the development of clinical therapeutics, including pain therapy.

\section{REFERENCES}

Arvidsson U, Dado RJ, Riedl M, Lee JH, Law PY, Loh HH, Elde R, Wessendorf MW (1995a) $\delta$-Opioid receptor immunoreactivity: distribution in brainstem and spinal cord, and relationship to biogenic amines and enkephalin. J Neurosci 15:1215-1235.

Arvidsson U, Riedl M, Chakrabarti S, Lee JH, Nakano AH, Dado RJ, Loh HH, Law PY, Wessendorf MW, Elde R (1995b) Distribution and targeting of a mu-opioid receptor (MOR1) in brain and spinal cord. J Neurosci 15:3328-3341.

Belcheva MM, Barg J, McHale R, Coscia CJ (1994) Naltrexone induces down- and upregulation of delta opioid receptors in rat brain regions. Brain Res Bull 35:69-72.

Bilsky EJ, Bernstein RN, Hruby VJ, Rothman RB, Lai J, Porecca F (1996) Characterization of antinociception to opioid receptor selective agonists after antisense oligodeoxynucleotide-mediated "knock-down" of opioid receptor in vivo. J Pharmacol Exp Ther 277:491-501.

Cahill CM, Lee M-C, Vincent JP, Beaudet A (1999) Increase in delta opioid receptor internalization following chronic morphine treatment. Soc Neurosci Abstr 25:883.6.

Cahill CM, McClellan KA, Morinville A, Hoffert C, Hubatsch D, O'Donnell D, Beaudet A (2001) Immunohistochemical distribution of delta opioid receptors in the rat CNS: evidence for somato-dendritic labeling and antigen-specific cellular compartmentalization. J Comp Neurol, in press.

Chen Y, Mestek A, Lui J, Hurley JA, Yu L (1993) Molecular cloning and functional expression of a $\mu$-opioid receptor from rat brain. Mol Pharmacol 44:8-12.

Cheng PY, Svingos AL, Wang H, Clarke CL, Jenab S, Beczkowska IW, Inturrisi CE, Pickel VM (1995) Ultrastructural immunolabeling shows prominent presynaptic vesicular localization of delta-opioid receptor within both enkephalin- and nonenkephalin-containing axon terminals in the superficial layers of the rat cervical spinal cord. J Neurosci 15:5976-5988.

Cheng PY, Liu-Chen L-Y, Pickel VM (1997) Dual ultrastructural immunocytochemical labeling of $\mu$ and $\delta$ opioid receptors in the superficial layers of the rat cervical spinal cord. Brain Res 778:367-380.

Coderre TJ, Fundytus ME, McKenna JE, Dalal S, Melzack R (1993)
The formalin test: a validation of the weighted scores method of behavioral pain rating. Pain 54:43-50.

Elde R, Arvidsson U, Riedl M, Vulchanova L, Lee JH, Dado R, Nakano A, Chakrabarti S, Zhang X, Loh HH, Law PY, Hökfelt T, Wessendorf M (1995) Distribution of neuropeptide receptors. New views of peptidergic neurotransmission made possible by antibodies to opioid receptors. Ann NY Acad Sci 757:390-404.

Evans CJ, Keith Jr DE, Morrison H, Magendzo K, Edwards RH (1992) Cloning of a delta opioid receptor by functional expression. Science 258:1952-1955.

Fukuda K, Kato S, Mori K, Nishi M, Takeshima H (1993) Primary structures and expression from cDNAs of rat opioid receptor $\delta$ - and $\mu$-subtypes. FEBS Lett 327:311-314.

Gaudriault G, Nouel D, Dal Farra C, Beaudet A, Vincent JP (1997) Receptor-induced internalization of selective peptidic $\mu$ and $\delta$ opioid ligands. J Biol Chem 272:2880-2888.

George SR, Fan T, Xie Z, Tse R, Tam V, Varghese G, O'Dowd BF (2000) Oligomerization of mu- and delta-opioid receptors. Generation of novel functional properties. J Biol Chem 275:26128-26135.

Goldstein A (1987) Binding selectivity profiles for ligands of multiple receptor types: focus on opioid receptors. Trends Pharmacol Sci 8:456459.

Gomes I, Jordan BA, Gupta A, Trapaidze N, Nagy V, Devi LA (2000) Heterodimerization of $\mu$ and $\delta$ opioid receptors: a role in opiate synergy. J Neurosci 20:RC110(1-5).

Gouardères C, Jhamandas K, Cridland R, Cros J, Quirion R, Zajac JM (1993) Opioid and substance $P$ receptor adaptations in the rat spinal cord following sub-chronic intrathecal treatment with morphine and naloxone. Neuroscience 54:799-807.

Hammond DL, Wang H, Nakashima N, Basbaum AI (1998) Differential effects of intrathecally administered delta and mu opioid receptor agonists on formalin-evoked nociception and on the expression of Fos-like immunoreactivity in the spinal cord of the rat. J Pharmacol Exp Ther 284:378-387.

Heyman JS, Vaught JL, Mosberg HI, Haaseth RC, Porecca F (1989) Modulation of mu mediated antinociception by delta agonists in the mouse: selective potentiation of morphine and normorphine by [D-Pen ${ }^{2}$, D-Pen ${ }^{5}$ ]enkephalin. Eur J Pharmacol 165:1-10.

Holtbäck U, Brismar H, DiBona GF, Fu M, Greengard P, Aperia A (1999) Receptor recruitment: a mechanism for interactions between $G$ protein-coupled receptors. Proc Natl Acad Sci USA 96:7271-7275.

Jiang Q, Mosberg HI, Porecca F (1990) Selective modulation of morphine antinociception, but not tolerance, by $\delta$ receptor agonists. Eur J Pharmacol 186:137-141

Jordan BA, Devi LA (1999) G-protein coupled receptor heterodimerization modulates receptor function. Nature 399:697-700.

Kest B, Lee CE, McLemore GL, Inturrisi CE (1996) An antisense oligodeoxynucleotide to the delta opioid receptor (DOR-1) inhibits morphine tolerance and acute dependence in mice. Brain Res Bull 39:185-188.

Kieffer BL, Befort K, Gaveriaux-Ruff C, Hirth CG (1992) The $\delta$-opioid receptor: isolation of a cDNA by expression cloning and pharmacological characterization. Proc Natl Acad Sci USA 89:12048-12052.

Ko JL, Arvidsson U, Williams FG, Law PY, Elde R, Loh HH (1999) Visualization of time-dependent redistribution of delta-opioid receptors in neuronal cells during prolonged agonist exposure. Brain Res Mol Brain Res 69:171-185.

Lee M-C, Cahill CM, Vincent JP, Beaudet A (2002) Internalization and trafficking of opioid receptor ligands in rat cortical neurons. Synapse, in press.

Malmberg AB, Yaksh TL (1992) Isobolographic and dose-response analyses of the interaction between intrathecal $\mathrm{mu}$ and delta agonists: effects of naltrindole and its benzofuran analogue (NTB). J Pharmacol Exp Ther 263:264-275.

Meng F, Xie G-X, Thompson RC, Mansour A, Goldstein A, Watson SJ, Akil H (1993) Cloning and pharmacological characterization of a rat $\kappa$ opioid receptor. Proc Natl Acad Sci USA 90:9954-9958.

Miyamoto Y, Portoghese PS, Takemori AE (1993) Involvement of delta opioid receptors in the development of morphine dependence in mice. J Pharmacol Exp Ther 264:1141-1145.

Morinville A, Cahill CM, Collier B, Beaudet A (2000) Mu opioid receptor-induced targeting of delta receptors to neuronal plasma membranes. Soc Neurosci Abstr 26:434.11.

Porecca F, Jiang Q, Tallarida RJ (1990) Modulation of morphine antinociception by peripheral $\left[\mathrm{Leu}^{5}\right]$ enkephalin: a synergistic interaction. Eur J Pharmacol 179:463-468.

Rothman RB, Danks JA, Jacobson AE, Burke Jr TR, Rice KC, Tortella FC, Holaday JW (1986) Morphine tolerance increases $\mu$-noncompetitive $\delta$ binding sites. Eur J Pharmacol 124:113-119.

Solomon RE, Gebhart GF (1994) Synergistic antinociceptive interactions among drugs administered to the spinal cord. Anesth Analg 78:1164-1172.

Stewart PE, Hammond DL (1993) Evidence for delta opioid receptor subtypes in rat spinal cord: studies with intrathecal naltriben, cyclic[D- 
Pen $^{2}$, D-Pen ${ }^{5}$ enkephalin and $\left[\mathrm{D}-\mathrm{Ala}^{2}\right.$, Glu $\left.^{4}\right]$ deltorphin. J Pharmacol Exp Ther 266:820-828.

Stroh T, Jackson AC, Sarret P, Dal Farra C, Vincent JP, Kreienkamp HJ, Mazella J, Beaudet A (2000) Intracellular dynamics of sst5 receptors in transfected COS-7 cells: maintenance of cell surface receptors during ligand-induced endocytosis. Endocrinology 141:354-365.

Thompson RC, Mansour A, Akil H, Watson SJ (1993) Cloning and pharmacological characterization of a rat mu opioid receptor. Neuron 11:903-913.

Wan Q, Xiong ZG, Man HY, Ackerley CA, Braunton J, Lu WY, Becker LE, MacDonald JF, Wang YT (1997) Recruitment of functional GABA(A) receptors to postsynaptic domains by insulin. Nature 388:686-690

Wang JB, Imai Y, Eppler CM, Gregor P, Spivak CE, Uhl GR (1993) Mu opiate receptor: cDNA cloning and expression. Proc Natl Acad Sci USA 60:10230-10234.
Yasuda K, Raynor K, Kong H, Breder CD, Takeda J, Reisine T, Bell GI (1993) Cloning and functional comparison of $\kappa$ and $\delta$ opioid receptors from mouse brain. Proc Natl Acad Sci USA 90:6736-6740.

Zadina JE, Harrison LM, Ge L-J, Kastin AJ, Chang SL (1994) Differential regulation of mu and delta opiate receptors by morphine, selective agonists and antagonists and differentiating agents in SH-SY5Y human neuroblastoma cells. J Pharmacol Exp Ther 270:1086-1096.

Zhang X, Bao L, Arvidsson U, Elde R, Hökfelt T (1998) Localization and regulation of the delta-opioid receptor in dorsal root ganglia and spinal cord of the rat and monkey: evidence for association with the membrane of large dense-core vesicles. Neuroscience 82:1225-1242.

Zhu Y, King MA, Schuller AG, Nitsche JF, Reidl M, Elde RP, Unterwald E, Pasternak GW, Pintar JE (1999) Retention of supraspinal delta-like analgesia and loss of morphine tolerance in $\delta$ opioid receptor knockout mice. Neuron 24:243-252. 